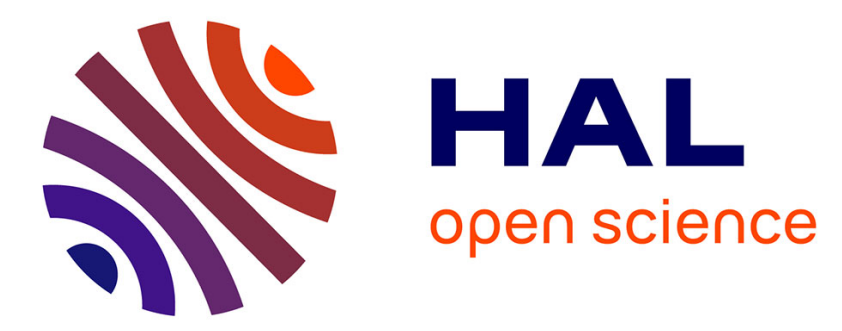

\title{
Microfluidics set-up rapidly measures solubility directly from powder
}

\author{
Guillem Peybernès, Romain A Grossier, Frédéric Villard, Philippe Letellier, \\ Mehdi Lagaize, Nadine A Candoni, Stéphane Veesler
}

\section{- To cite this version:}

Guillem Peybernès, Romain A Grossier, Frédéric Villard, Philippe Letellier, Mehdi Lagaize, et al.. Microfluidics set-up rapidly measures solubility directly from powder. Organic Process Research and Development, 2018, 22, pp.1856-1860. 10.1021/acs.oprd.8b00300 . hal-01899746v2

\section{HAL Id: hal-01899746 \\ https://hal.science/hal-01899746v2}

Submitted on 31 Oct 2018

HAL is a multi-disciplinary open access archive for the deposit and dissemination of scientific research documents, whether they are published or not. The documents may come from teaching and research institutions in France or abroad, or from public or private research centers.
L'archive ouverte pluridisciplinaire HAL, est destinée au dépôt et à la diffusion de documents scientifiques de niveau recherche, publiés ou non, émanant des établissements d'enseignement et de recherche français ou étrangers, des laboratoires publics ou privés. 


\section{Microfluidics set-up rapidly measures solubility directly from powder}

Guillem Peybernès ${ }^{1,2}$, Romain Grossier ${ }^{1}$, Frédéric Villard ${ }^{2}$, Philippe Letellier ${ }^{2}$, Mehdi Lagaize $^{1}$, Nadine Candoni ${ }^{1}$, Stéphane Veesler ${ }^{1 *}$,

${ }^{1}$ CNRS, Aix-Marseille University, CINaM (Centre Interdisciplinaire de Nanosciences de Marseille), Campus de Luminy, Case 913, F-13288 Marseille Cedex 09, France,

${ }^{2}$ Technologie Servier, 27 Rue EugèneVignat,45000 Orléans, France

*veesler@cinam.univ-mrs.fr 


\section{Microfluidics set-up rapidly measures solubility directly from powder}

Guillem Peybernès ${ }^{1,2}$, Romain Grossier ${ }^{1}$, Frédéric Villard ${ }^{2}$, Philippe Letellier ${ }^{2}$, Mehdi Lagaize $^{1}$, Nadine Candoni ${ }^{1}$, Stéphane Veesler ${ }^{1 *}$,

${ }^{1}$ CNRS, Aix-Marseille University, CINaM (Centre Interdisciplinaire de Nanosciences de Marseille), Campus de Luminy, Case 913, F-13288 Marseille Cedex 09, France,

${ }^{2}$ Technologie Servier, 27 Rue EugèneVignat,45000 Orléans, France

*veesler@cinam.univ-mrs.fr

\section{FOR TABLE OF CONTENTS ONLY}

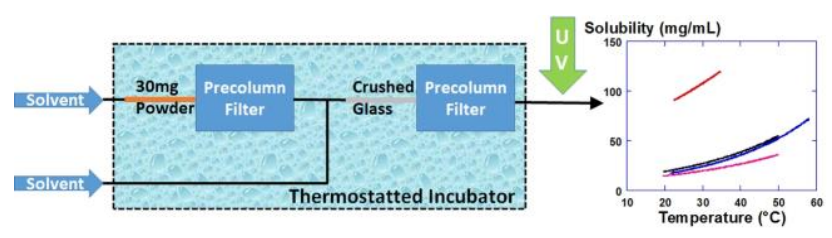




\title{
Microfluidics set-up rapidly measures solubility directly from powder
}

\author{
Guillem Peybernès ${ }^{1,2}$, Romain Grossier ${ }^{1}$, Frédéric Villard ${ }^{2}$, Philippe Letellier ${ }^{2}$, Mehdi Lagaize $^{1}$, Nadine \\ Candoni ${ }^{1}$, Stéphane Veesler ${ }^{1 *}$,
}

${ }^{1}$ CNRS, Aix-Marseille University, CINaM (Centre Interdisciplinaire de Nanosciences de Marseille), Campus

de Luminy, Case 913, F-13288 Marseille Cedex 09, France,

${ }^{2}$ Technologie Servier, 27 Rue EugèneVignat,45000 Orléans, France

*veesler@cinam.univ-mrs.fr

\begin{abstract}
This communication presents a new microfluidics device for solubility measurement based on the generation of saturated solutions starting from powder and compatible with all solvents and molecules. This device is simple and easily incorporated into any laboratory, even those not specialized in microfluidics. We described the method used to measure solubility, applied here to the pharmaceutical molecules paracetamol and gliclazide in different solvents. The device rapidly measures the solubility of a compound at a variety of temperatures ranging from 20 to $60^{\circ} \mathrm{C}$ using extremely small quantities (here, only $30 \mathrm{mg}$ ) of material, with a concentration range from $\mathrm{mg} / \mathrm{mL}$ to hundreds of $\mathrm{mg} / \mathrm{mL}$.
\end{abstract}

\section{KEY WORDS}

Solubility, Crystallization, Microfluidics, Pharmaceutical molecules

\section{INTRODUCTION}

Crystallization has a wide range of industrial and academic applications. Controlling the end crystals and their properties usually strongly depends on the starting position in the phase diagram and the chemical composition. This requires a thorough understanding of the phase diagram. Thus, measuring solubility curves is a crucial step in crystallization studies and process development. Different methods are used to measure solubility, all based on the principle of measuring the concentration of a saturated solution. For instance, attenuated total reflection - Fourier transform infrared (ATR-FTIR) $)^{1-2}$ and Raman ${ }^{3}$ spectroscopies were reported for in situ solubility measurements. Small-scale ( $\mathrm{mL}$ range) dedicated set-ups using turbidimetry ${ }^{4-5}$ and optical microscopy ${ }^{6}$ were also developed. But sometimes only an extremely small quantity of material is available, which poses the problem of further reducing material consumption. Thus, there is a need for a set-up and a methodology to obtain reliable solubility in extremely small volume ( $\mu \mathrm{L}$ range) and different solvents. The microfluidics systems increasingly used over the past decade ${ }^{7}$ could be the answer: they can manipulate fluids on the submillimeter scale ${ }^{8-9}$. Here, we propose a simple and versatile microfluidics-based tool for solubility measurements. Suitable for different conditions, chemical mediums and temperatures, our device is based on the generation of saturated solutions starting directly from powder and compatible with most of solvents and molecules. The device measures solubility with extremely small quantities and is easily incorporated into any laboratory, even those not specialized in microfluidics. In this communication, we describe our setup and how it is used to measure solubility. Here it is applied to the pharmaceutical molecules paracetamol and gliclazide, in both aqueous and organic solvents. The device allows us to measure the entire solubility curve of a compound at a variety of temperatures ranging from 20 to $60^{\circ} \mathrm{C}$ using extremely small quantity of material (here, only $30 \mathrm{mg}$ ) in just 4 hours.

\section{EXPERIMENTAL SECTION}

\section{Testing molecules}

Paracetamol (4-Acetamidophenol), stable form I, was purchased from Alfa Aesar (A11240, batch 10162567). Gliclazide, $\mathrm{C}_{15} \mathrm{H}_{21} \mathrm{~N}_{3} \mathrm{O}_{3} \mathrm{~S}$ - 1-(cis-3-Azabicyclo[3.3.0]oct-3-yl)-3-p-tolylsulphonylurea, was furnished by Technologie Servier (TES) and is used in the treatment of non-insulin-dependent diabetes mellitus.

Solvents are analytical grade. 


\section{Microfluidics set-up}

The principle of our microfluidics solubility measurement set-up is that the solvent flows through a powder bed blocked by a filter. At the outlet of the filter, due to the molecule dissolving the solution concentration is at saturation. This saturated solution is then analyzed online by a UV-Vis spectrometer. From the absorbance measured with this device, the equilibrium concentration is deduced with Beer-Lambert's law. It is then possible to measure solubility at a variety of temperatures by controlling the powder bed temperature at the filter outlet.

All the set-ups presented in this paper are PEEK (polyether ether ketone) devices based on HPLC techniques (IDEX Health and Science). T-junctions, precolumn filters, and PFA (Perfluoroalkoxy alkane) tubing, which are resistant to many solvents, render the device applicable to mineral, organic and biological materials. The solutions are loaded using separate syringes and a programmable syringe pump (neMESYS, cetoni GmbH) controls the flow rates of the different fluids.

\section{Proof of concept of reaching saturated solution from powder (fig.1)}

We first constructed a microfluidics system based on dissolving $30 \mathrm{mg}$ of a powder placed in a $1 \mathrm{~mm}$ inner diameter (ID) tube connected to a precolumn filter of $0.5 \mu \mathrm{m}$ (IDEX Health and Science) (fig.1b). Syringes, powder and precolumn filter are placed in an incubator (fig. S1, supplementary information file) allowing temperature control from room temperature to $65^{\circ} \mathrm{C}^{10}$ (ANACRISMAT). The solute concentration in the outlet flow was measured using a real-time on-line method as described previously ${ }^{11}$, UV-Vis absorbance spectroscopy. We coupled an on-line UV detector (USB2000+, Ocean optics) to the PFA tubing after the Tjunction using a home-made 3D-printed UV cell adapted for this purpose from Zhang et al. ${ }^{11}$ (fig. 1c). Selecting one wavelength from the UV-visible absorption spectra of Gliclazide in isopropanol (fig. S2, supplementary information file) we measured the evolution over time of the absorbance (here at $274 \mathrm{~nm}$, fig.2).Raising temperature from $25^{\circ} \mathrm{C}$ to $34.7^{\circ} \mathrm{C}$ we observed an absorbance plateau after less than 2 minutes, corresponding to the equilibrium concentration of Gliclazide in isopropanol at $34.7^{\circ} \mathrm{C}$. This simple set-up and experiment consumed only $30 \mathrm{mg}$ of powder. One limitation is that calculating the concentration from absorbance measurements requires that the absorbance be calibrated, necessitating additional material. Applying the BeerLambert law also limits the concentration range that can be addressed (fig. S3, supplementary information file).
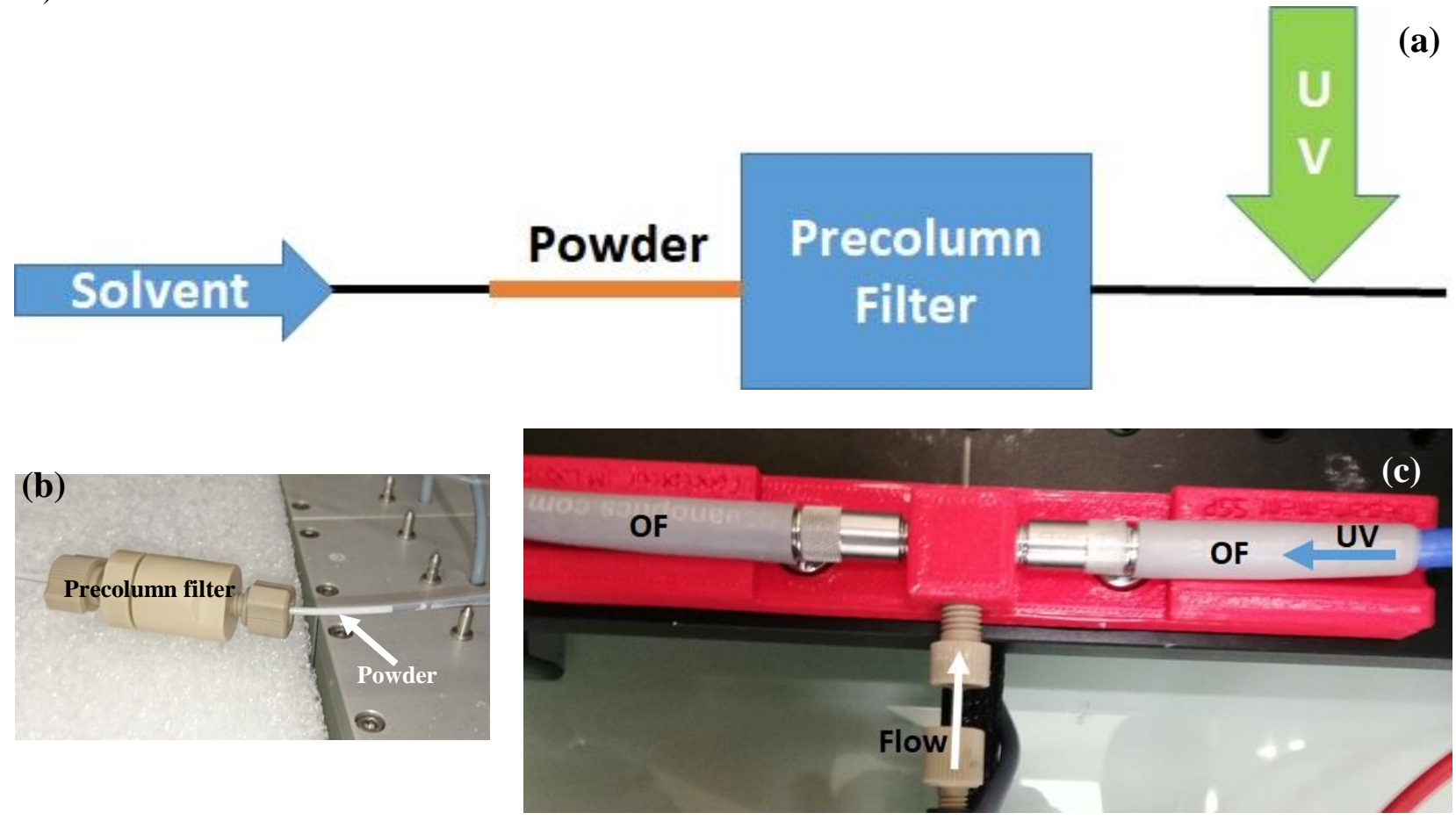

Figure 1. (a) Scheme of the dissolution set-up, (b) powder placed in a 1 mm inner diameter (ID) tube connected to a precolumn filter and, (c) UV cell, optical fiber (OF) light source (UV) from the right to UV spectrophotomer (left). 


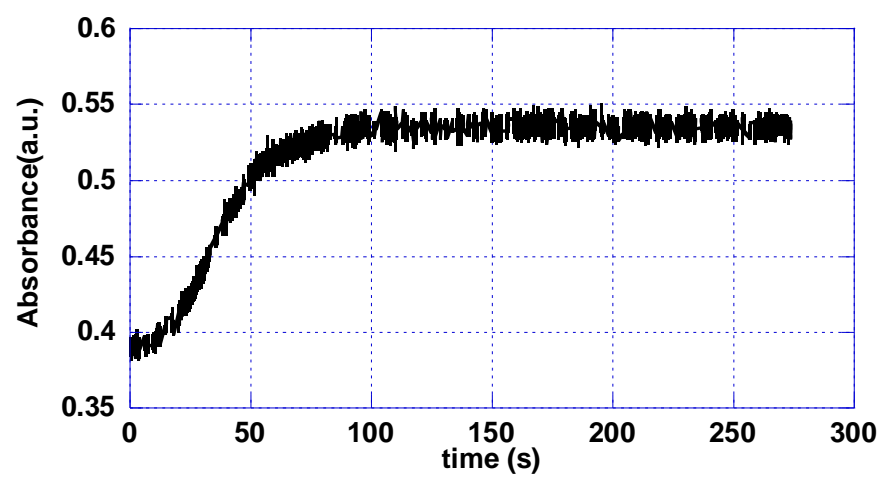

Figure 2. Absorbance at $274 \mathrm{~nm}$, of gliclazide in isopropanol, at the outlet of the precolumn filter, temperature is changed from $25^{\circ} \mathrm{C}$ to $34.7^{\circ} \mathrm{C}$.

\section{Overcoming limitations (fig.3)}

To overcome this concentration limitation we added to the first set-up a dilution step using a microfluidics Tjunction and a second precolumn filter. The T-junction was used to inject the same solvent at the filter outlet so as to be in the linear domain of the absorbance with concentration. The second precolumn filter was filled with crushed glass and added downstream to ensure rapid mixing of solutions. The 2 columns and the Tjunction were placed in a temperature-controlled incubator (from room temperature to $50^{\circ} \mathrm{C}$ ).

In addition, the calibration step was replaced by a new procedure involving only measuring the absorbance of a standard solution of $1 \mathrm{mg} / \mathrm{mL}$. This low concentration guaranteed that we were in the linear part of the absorbance.

Note that using a $2 \mathrm{~mL}$ standard solution which consumes only $2 \mathrm{mg}$ of powder, enables us to estimate the solubility via bracketing at room temperature (see fig. S4, supplementary information file, for a flowchart of the solubility estimation via successive addition of solvent during the preparation of the standard solution).

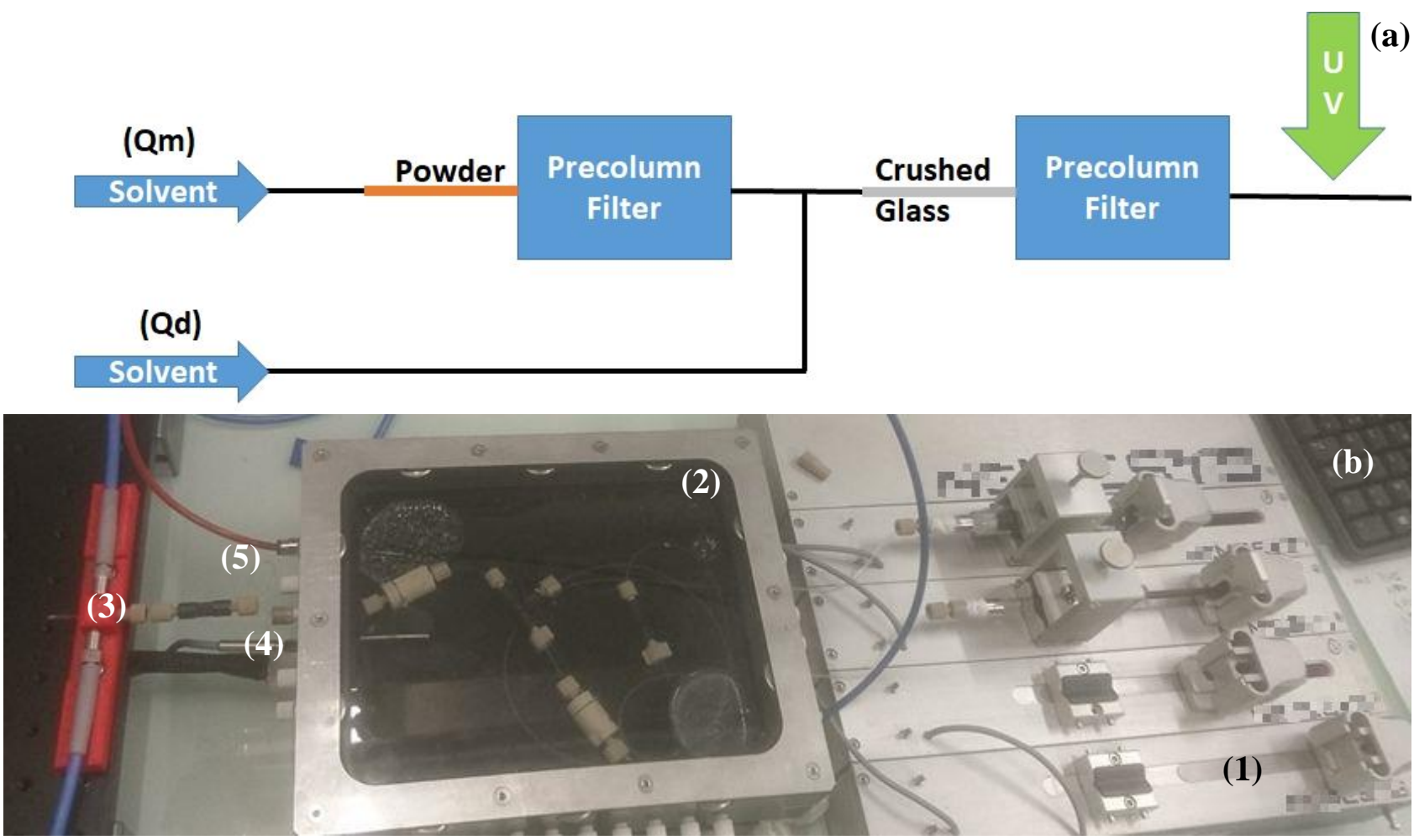

Figure 3. (a) Scheme and (b) photograph of the home-made microfluidics set-up: (1) syringe pump, (2) temperature controlled incubator, (3) UV cell, (4) temperature probe and (5) outside loop insuring solution thermal equilibrium to room temperature. 


\section{Solubility measurement using the set-up}

The experimental protocol consists in first measuring the intensity of the UV light transmitted by the pure solvent solution $\left(\mathrm{I}_{0}\right)$ and by the standard solution $\left(\mathrm{I}_{\text {standard }}\right)$ as a reference. Second, the solvent is injected at a given flow rate $\left(\mathrm{Q}_{\mathrm{m}}\right)$ to dissolve the powder placed in the tube and the transmitted intensity is measured and compared to that of the standard solution. Third, this solution is diluted by a stepwise increase of the flow rate of the solvent $\left(\mathrm{Q}_{\mathrm{d}}\right)$ at the filter outlet until the transmitted intensities of diluted and standard solutions match (fig.4a), for an application see figure $4 \mathrm{~b}$. When transmitted intensities of diluted and standard solutions match, the solubility value $\left(\mathrm{C}_{\mathrm{s}}\right)$ is given by:

$$
\mathbf{C}_{\mathrm{s}}=\mathbf{C}_{\text {standard }} /\left(\mathbf{Q}_{\mathrm{m}} /\left(\mathbf{Q}_{\mathrm{m}}+\mathbf{Q}_{\mathrm{d}}\right)\right)
$$

where $\mathrm{C}_{\text {standard }}$ is the concentration of the standard solution.

Note that the dilution is defined by the ratio $Q_{m} /\left(Q_{m}+Q_{d}\right)$ of Eq.1 with $Q_{m}$ and $Q_{d}$ variables. In practice, it is impossible to have exact matching between transmitted intensities of diluted and standard solutions; thus, to be rigorous, a correction needs to be made using the absorbances according to Eq.2 (here we suppose that the Beer-Lambert law applies).

$\mathbf{C}_{\text {meas }} / \mathbf{A}_{\text {meas }}=\mathbf{C}_{\text {standard }} / \mathbf{A}_{\text {standard }}$

Where $\mathrm{A}_{\text {standard }}=-\log \left(\mathrm{I}_{\text {standard }} / \mathrm{I}_{0}\right)$ and $\mathrm{A}_{\text {meas }}=-\log \left(\mathrm{I}_{\text {meas }} / \mathrm{I}_{0}\right)$ represent the absorbances of the standard solution and experimental measurement (fig. 4).

$$
\mathbf{C}_{\mathbf{s}}=\mathbf{C}_{\mathbf{m e a s}} /\left(\mathbf{Q}_{\mathbf{m}} /\left(\mathbf{Q}_{\mathbf{m}}+\mathbf{Q}_{\mathbf{d}}\right)\right)
$$

This operation is repeated for all temperatures and thus provides the solubility at a variety of temperatures in a given solvent. Using this method it is also possible, when powder is not completely dissolved, to change the solvent by replacing syringes with others containing a new solvent. It takes only 4 hours and approximately $30 \mathrm{mg}$ of powder to obtain one solubility curve for a solvent at 6 different temperatures ranging from 20 to $60^{\circ} \mathrm{C}$.

Note that adding a dilution step prevents the solution from unwanted nucleation events during the measurement.

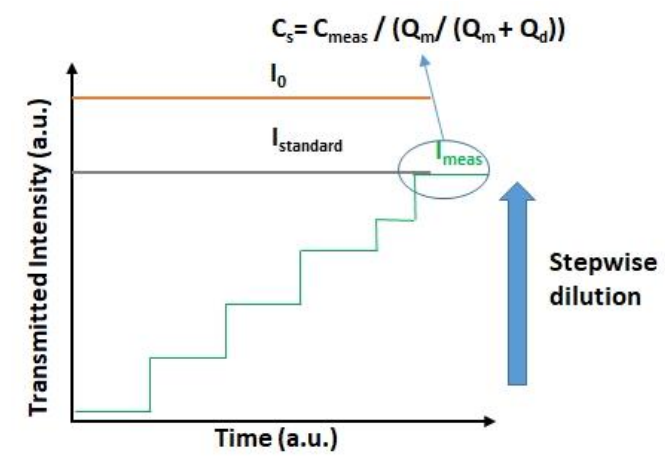

(a)

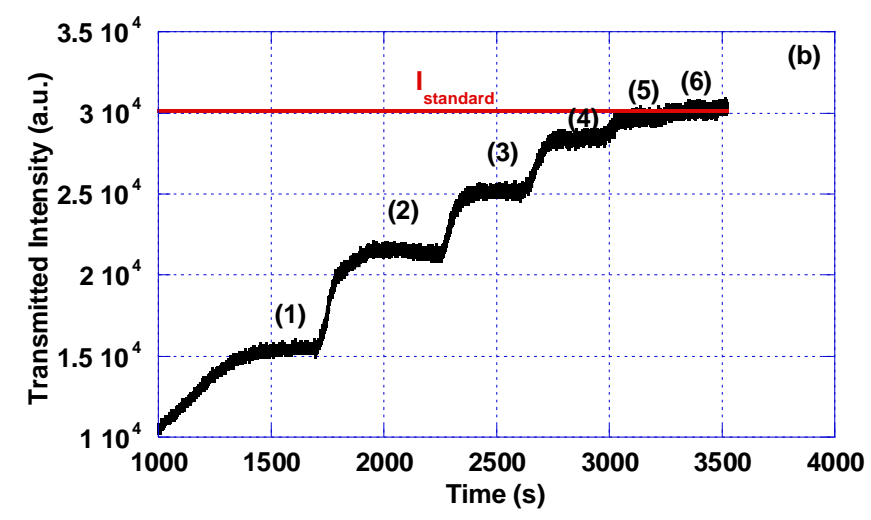

Figure 4. (a) Principle of the stepwise dilution for solubility measurement, and (b) Evolution of the transmitted intensity at $274 \mathrm{~nm}$ as a function of time with increasing dilution ratio, with $I_{0}=40268, I_{\text {standard }}=30165$ and $I_{\text {mes }}=30200$ in a.u.. Plateau (1) corresponds to $Q_{m}=1000 \mu \mathrm{L} / \mathrm{h}$ and $Q_{d}=1000 \mu \mathrm{L} / \mathrm{h}$, (2) to $Q_{m}=500 \mu \mathrm{L} / \mathrm{h}$ and $Q_{d}=1000 \mu \mathrm{L} / \mathrm{h}$, , (3) to $Q_{m}=500 \mu \mathrm{L} / \mathrm{h}$ and $Q_{d}=1500 \mu \mathrm{L} / \mathrm{h}$, , (4) to $Q_{m}=500 \mu \mathrm{L} / \mathrm{h}$ and $Q_{d}=2000 \mu \mathrm{L} / \mathrm{h}$, , (5) to $Q_{m}=500 \mu \mathrm{L} / \mathrm{h}$ and $Q_{d}=2250 \mu \mathrm{L} / \mathrm{h}$ and (6) to $Q_{m}=500 \mu \mathrm{L} / \mathrm{h}$ and $Q_{d}=2350 \mu \mathrm{L} / \mathrm{h}$. 


\section{SOLUBILITY CURVES}

Solubility measurements of our model compound paracetamol in 3 solvents, water, acetonitrile and isopropanol, were performed to demonstrate the reliability of the set-up. Our data (data available on request) are here compared (fig. 5a-c) to findings ${ }^{12-18}$ obtained by various techniques: equilibration of a paracetamol suspension at different temperatures and titration of the supernatant by weighing the dry residue ${ }^{12,15,18}$, UV spectrophotometry ${ }^{13-14,17}$, or refractive indexes. ${ }^{16}$ Our solubility data compare well with data from the literature for paracetamol. Moreover, the solubility range accessible is from $\mathrm{mg} / \mathrm{mL}$ to hundreds of $\mathrm{mg} / \mathrm{mL}$.
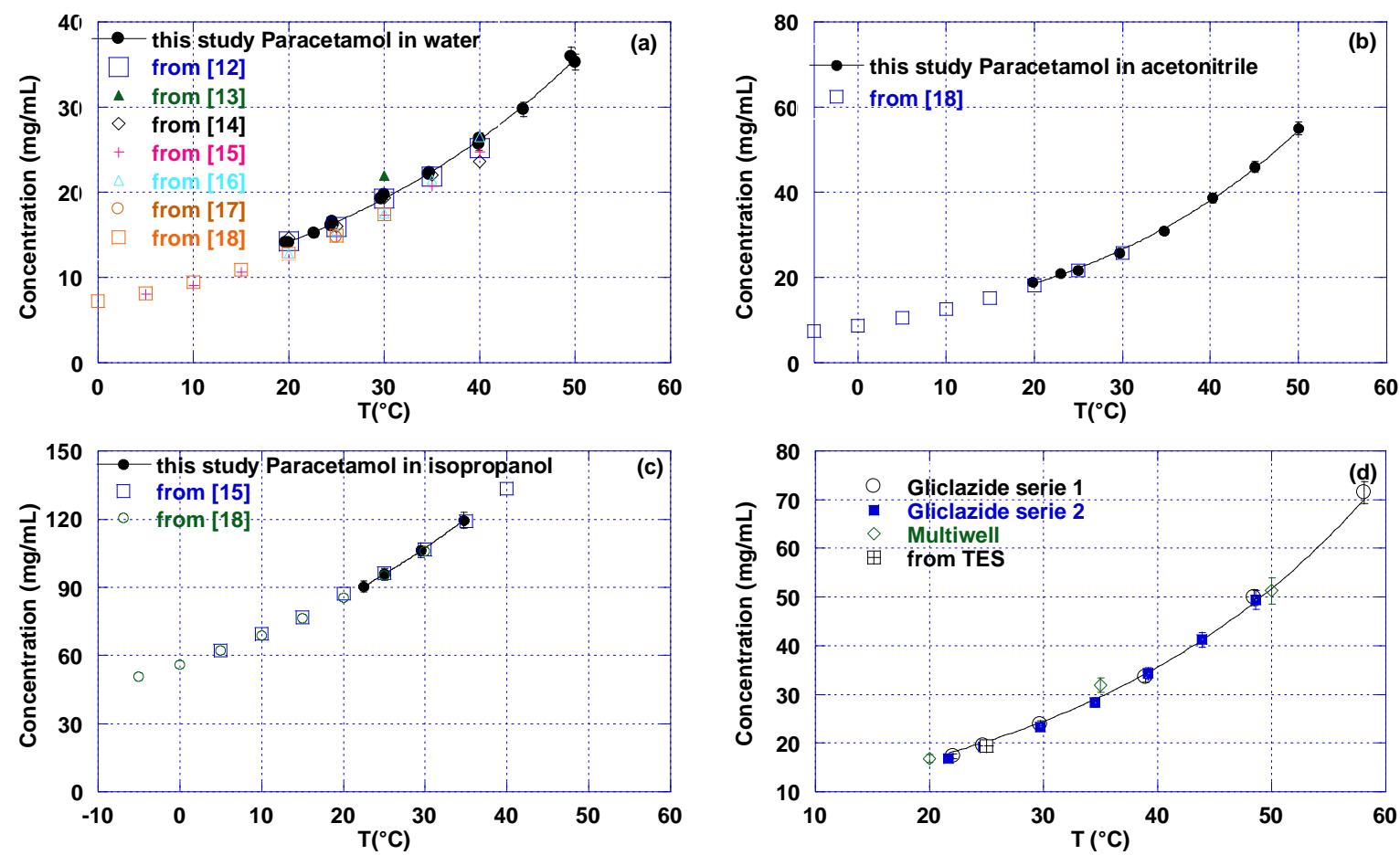

Figure 5. Solubility of Paracetamol (a) in water, $(b)$ in acetonitrile, $(c)$ in isopropanol and (d) solubility of Gliclazide in acetonitrile. The curves are exponential fits to our measurements. The error was estimated to 3\% (taking into account powder weighing, UV dosing and syringe pump flow rates)

We also performed solubility measurements for gliclazide from TES, who provided the solubility in acetonitrile at $25^{\circ} \mathrm{C}$. Here, to compare two methods of solubility measurement, we first used the methodology developed by Detoisien et al. ${ }^{6}$ with a multiwell set-up. This required consuming $>250 \mathrm{mg}$ of material for 1 solvent at 3 different temperatures and took 2 days. Then, we performed two sets of experiments using our new microcrofluidics set-up and the methodology described above. Figure 5d compares the different set-ups and methodologies. Data are consistent between methods with very good reproducibility. However, our new set-up consumed only $30 \mathrm{mg}$ of material for 1 solvent at 7 temperatures and took only 4 hours.

\section{CONCLUSION}

This communication presents a new microfluidics device for solubility measurement based on the generation of saturated solutions starting from powder and compatible with all solvents and molecules. This device is simple and easily incorporated into any laboratory, even those not specialized in microfluidics. We have described the method used to measure solubility, applied here to the pharmaceutical molecules paracetamol and gliclazide in different solvents. The device rapidly measures the solubility of a compound at a variety of temperatures ranging from 20 to $60^{\circ} \mathrm{C}$ using extremely small quantities (here, only 30mg) of material, with a concentration range from $\mathrm{mg} / \mathrm{mL}$ to hundreds of $\mathrm{mg} / \mathrm{mL}$. 
ACKNOWLEDGMENTS: We thank Technologie Servier for financial support. We are grateful to T. Bactivelane (CINaM) and M. Audiffren (ANACRISMAT) for technical assistance. We thank Marjorie Sweetko for English revision.

\section{SUPPLEMENTARY MATERIAL}

See supplementary material for Temperature controlled incubator, UV-visible absorption spectra of Gliclazide in isopropanol and the flowchart of the solubility estimation.

\section{REFERENCES:}

1. Dunuwila, D. D.; Berglund, K. A., ATR FTIR spectroscopy for in situ measurement of supersaturation. J. Cryst. Growth 1997, 179 (1-2), 185-193.

2. Lewiner F.; Klein J.P.; Puel F.; Févotte G., On-line ATR FTIR measurement of supersaturation during solution crystallization processes. Calibration and applications on three solute/solvent systems. Chem. Engineering Science 2001, 56, 2069-2084.

3. Schwartz A.M.; Berglund K.A., The use of Raman spectroscopy for in situ monitoring of lysozyme concentration during crystallization in a hanging drop. J. Crystal Growth 1999, 203, 599603.

4. Yi, Y.; Hatziavramidis, D.; Myerson, A. S.; Waldo, M.; Beylin, V. G.; Mustakis, J., Development of a Small-Scale Automated Solubility Measurement Apparatus. Ind. Eng. Chem. Res. 2005, 44 (15), 5427-5433.

5. Jiang, S.; Ter Horst, J. H., Crystal Nucleation Rates from Probability Distributions of Induction Times. Cryst. Growth Des. 2011, 11 (1), 256-261.

6. Detoisien, T.; Forite, M.; Taulelle, P.; Teston, J.; Colson, D.; Klein, J. P.; Veesler, S., A Rapid Method for Screening Crystallization Conditions and Phases of an Active Pharmaceutical Ingredient. Organic Process Research \& Development 2009, 13 (6), 1338-1342.

7. $\quad$ Leng J.; Salmon J.B., Microfluidic crystallization. Lab on a Chip 2009, 9, 24-34.

8. Squires, T. M.; Quake, S. R., Microfluidics: Fluid physics at the nanoliter scale. Rev. Mod. Phys. 2005, 77 (3), 977.

9. $\quad$ Lorber N.; Sarrazin F.; Guillot P.; Panizza P.; Colin A.; Pavageau B.; Hany C.; Maestro P.; Marre S.; Delclos T.; Aymonier C; Subra P.; Prat L.; Gourdon C.; Mignard E, Some recent advances in the design and the use of miniaturized droplet-based continuous process: Applications in chemistry and high-pressure microflows Lab on a Chip 2011, 11, 779-787.

10. Zhang, S.; Ferté, N.; Candoni, N.; Veesler, S., Versatile Microfluidic Approach to Crystallization. Organic Process Research \& Development 2015, 19, 1837-1841.

11. Zhang, S.; Gerard, C. J. J.; Ikni, A.; Ferry, G.; Vuillard, L. M.; Boutin, J. A.; Ferte, N.; Grossier, R.; Candoni, N.; Veesler, S., Microfluidic platform for optimization of crystallization conditions. J. Cryst. Growth 2017, 472, 18-28.

12. Bustamante, P.; Romero, S.; Peña, A.; Escalera, B.; Reillo, A., Enthalpy-entropy compensation for the solubility of drugs in solvent mixtures: Paracetamol, acetanilide, and nalidixic acid in dioxane-water. J. Pharm. Sci. 1998, 87 (12), 1590-1596.

13. Nagai, T.; Prakongpan, S., Solubility of Acetaminophen in Cosolvents. Chem. Pharm. Bull. (Tokyo) 1984, 32 (1), 340-343.

14. Bustamante, P.; Romero, S.; Reillo, A., Thermodynamics of Paracetamol in Amphiprotic and Amphiprotic-aprotic Solvent Mixtures. Pharmaceutical Sciences 1995, 1, 505-507.

15. Hojjati, H.; Rohani, S., Measurement and Prediction of Solubility of Paracetamol in Water-Isopropanol Solution. Part 1. Measurement and Data Analysis. Organic Process Research \& Development 2006, 10 (6), 1101-1109.

16. Jiménez, J. A.; Martínez, F., Thermodynamic Study of the Solubility of Acetaminophen in Propylene Glycol + Water Cosolvent Mixtures. J. Braz. Chem. Soc. 2006, 17, 125-134. 
17. Jouyban, A.; Chan, H.-K.; Chew, N. Y. K.; Khoubnasabjafari, M.; Acree, J. W. E., Solubility Prediction of Paracetamol in Binary and Ternary Solvent Mixtures Using Jouyban\&ndash;Acree Model. Chem. Pharm. Bull. 2006, 54 (4), 428-431.

18. Granberg, R. A.; Rasmuson, Å. C., Solubility of Paracetamol in Pure Solvents. J. Chem. Eng. Data 1999, 44 (6), 1391-1395. 


\section{Supplementary Information File}

\section{Microfluidics set-up rapidly measures solubility directly from powder.}

Guillem Peybernès ${ }^{1,2}$, Romain Grossier ${ }^{1}$, Frédéric Villard ${ }^{2}$, Philippe Letellier ${ }^{2}$, Mehdi Lagaize ${ }^{1}$, Nadine Candoni ${ }^{1}$, Stéphane Veesler ${ }^{1}$,

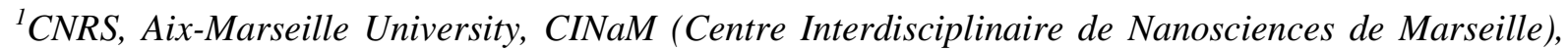
Campus de Luminy, Case 913, F-13288 Marseille Cedex 09, France,

${ }^{2}$ Technologie Servier, 27 Rue EugèneVignat,45000 Orléans, France

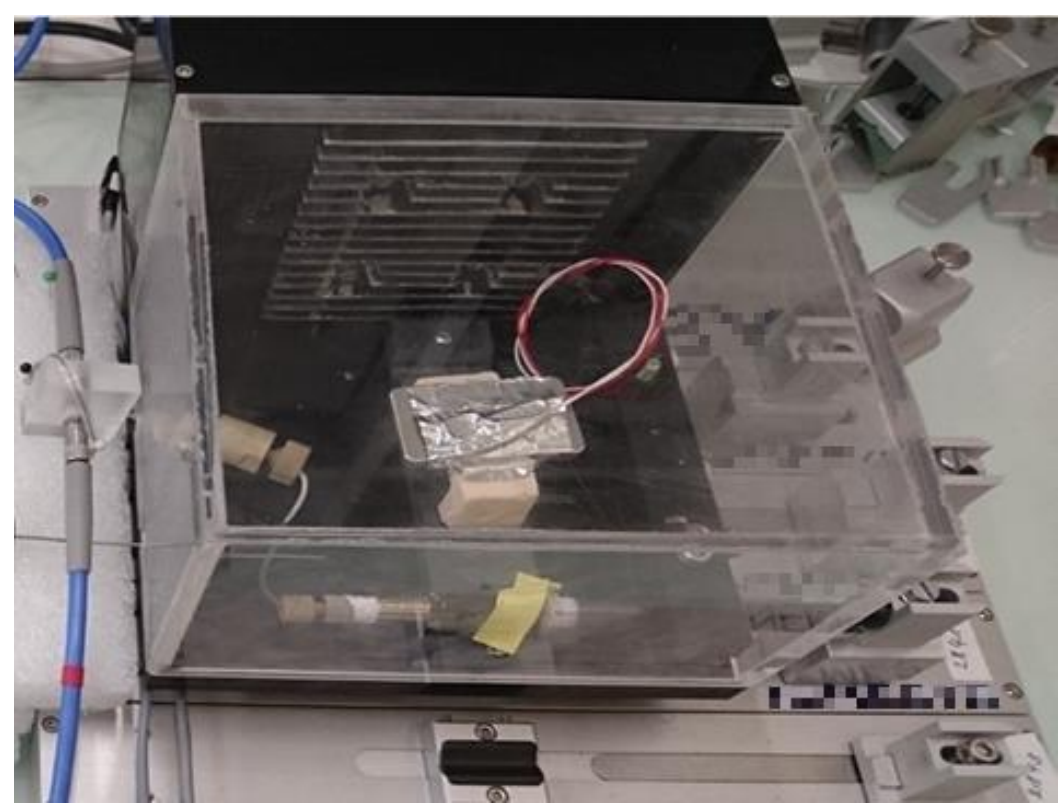

Figure S1. Temperature controlled incubator.

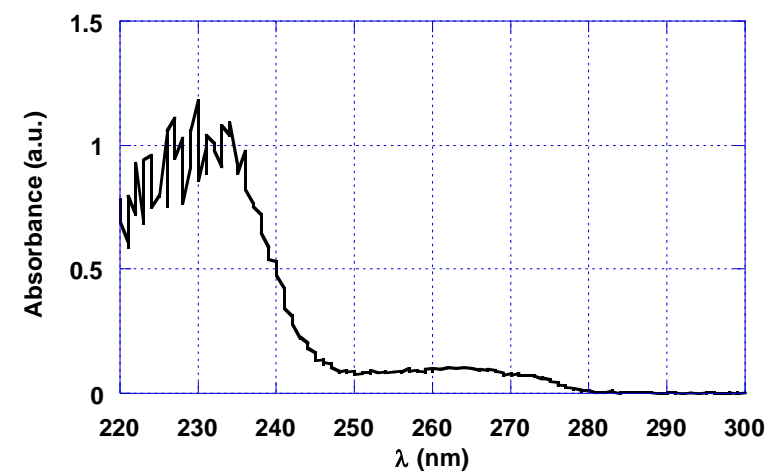

Figure S2. UV-visible absorption spectra of Gliclazide in isopropanol at room temperature, light source: DTMINI-2-GS and spectrophotometer USB2000+ from Ocean Optics. 


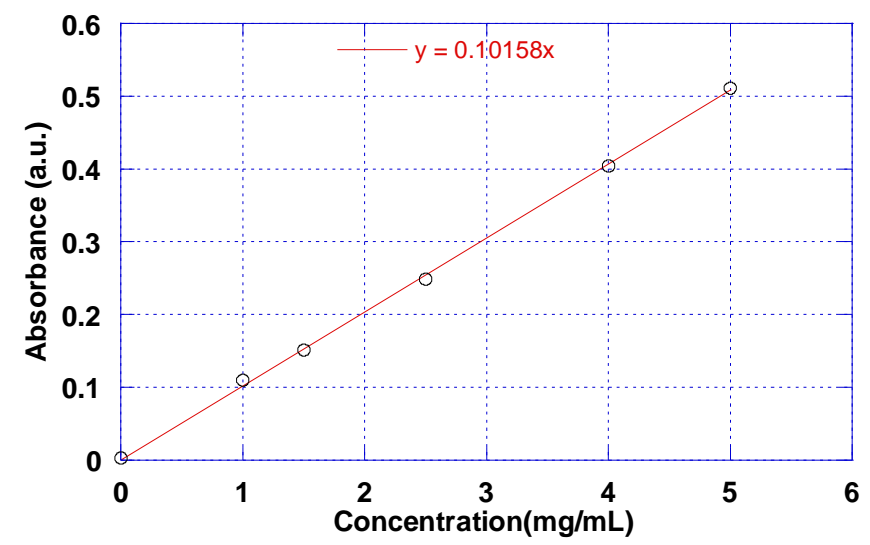

Figure S3. Linear part of the absorbance curve in function of the Gliclazide concentration in isopropanol at 274nm and at room temperature, light source: DT-MINI-2-GS and spectropotometer USB2000+ from Ocean Optics.

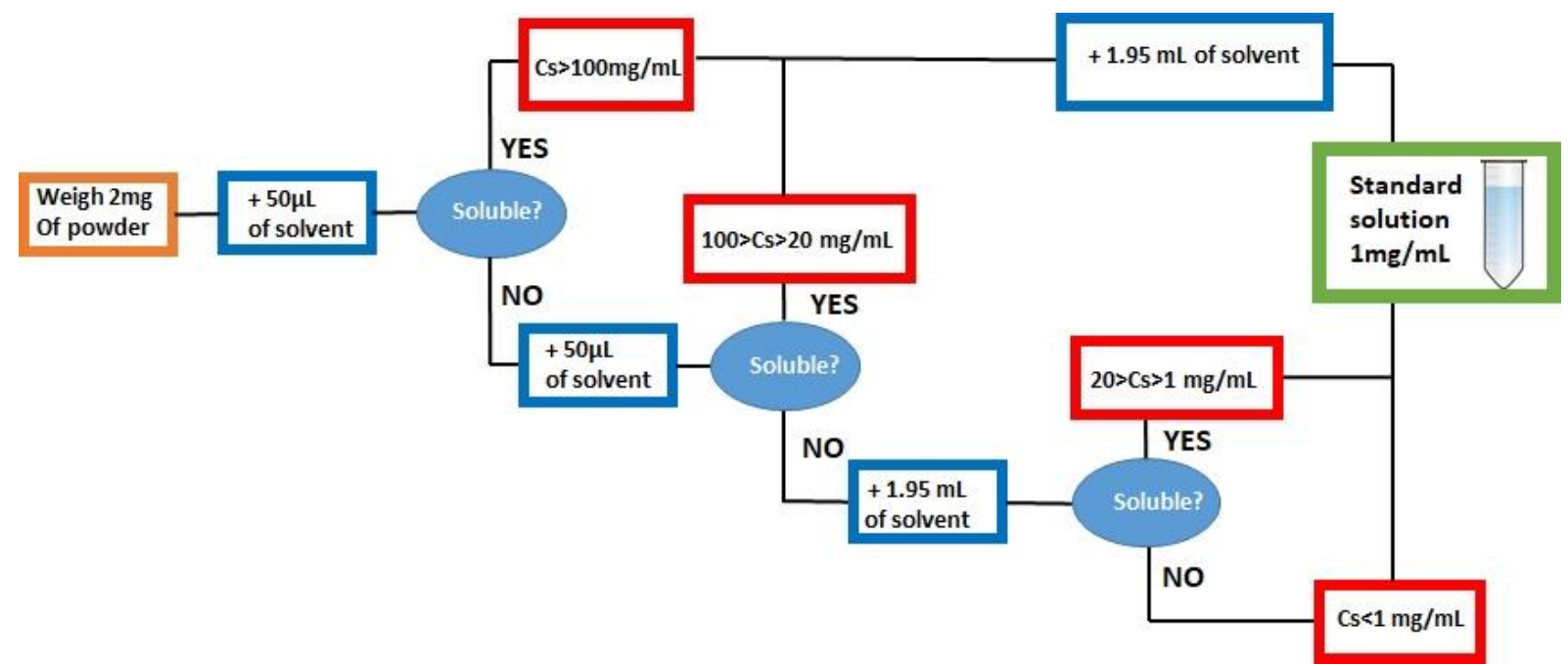

Figure S4. Flowchart of the solubility estimation (bracketing) via successive addition of solvent during the preparation of the standard solution. 